\title{
PKM Kelompok Perempuan Pengolah Ikan Cakalang Di Kelurahan Girian Bawah Kecamatan Girian Kota Bitung Provinsi Sulawesi Utara
}

\author{
Daisy Monica Makapedua ${ }^{*}$, Helen Jenny Lohoo ${ }^{1}$ \\ ${ }^{1}$ Fakultas Perikanan dan Ilmu Kelautan, \\ Universitas Sam Ratulangi Manado, 95115, Sulawesi Utara, Indonesia \\ *Penulis Korespondensi. Email: $\underline{\text { dmmakapedua@unsrat.ac.id }}$
}

\begin{abstract}
ABSTRAK
Pengolahan ikan cakalang asap merupakan produk olahan ikan tradisional khas Sulawesi Utara. Cakalang asap dalam masyarakat setempat disebut "cakalang fufu" merupakan salah satu produk ikan Sulawesi Utara yang banyak dikonsumsi oleh masyarakat sekitar dan wisatawan domestik yang berkunjung ke kota Manado dan Bitung. Permintaan ikan asap terus meningkat, baik dari dalam maupun luar Sulut. Pasar ikan asap kini berkembang pesat. Hal tersebut perlu diimbangi dengan peningkatan produksi cakalang asap yang berkualitas, bersih, dan dikemas dengan baik. Beberapa permasalahan yang dihadapi kelompok pengolah ikan (rekanan), seperti: kualitas bahan baku, cara pengolahan, penggunaan pewarna, dan pengemasan produk. Penerapan ilmu pengetahuan dan teknologi untuk pengabdian masyarakat dimaksudkan untuk memberikan pendidikan dan pelatihan yang melibatkan kelompok pengolahan ikan khususnya kelompok perempuan pengolah. Dengan melakukan kegiatan ini, kelompok perempuan pengolah dapat terlibat langsung untuk mengikuti setiap langkah yang telah ditetapkan bersama untuk mengatasi permasalahan guna meningkatkan produksi yang berkualitas, higienis dan sanitasi pangan serta peningkatan produksi dan produksi yang berkelanjutan. memperluas pasar. Kegiatan ini memberikan manfaat bagi kelompok pengolah ikan khususnya kelompok perempuan untuk memperbaiki perekonomian keluarga dan meningkatkan kesejahteraan masyarakat, serta pengembangan hasil perikanan di Sulawesi Utara.
\end{abstract}

Kata kunci: Cakalang asap, Kelompok Perempuan, Sanitasi dan kebersihan

\section{ABSTRACT}

Processing of smoked skipjack is traditionally processed fish products typical of North Sulawesi. Smoked skipjack as a local people called "cakalang fufu" is one of North Sulawesi fish product which mostly consumpted by the local community and the domestic tourists who visited Manado and Bitung city. Request smoked fish continues to increase, both from inside and outside of North Sulawesi. Smoked fish market is now growing rapidly. This should be offset by increasing the production of smoked skipjack with quality, cleanliness, and proper packaging. Some of the problems facing a group of fish processors (partner), such as: the quality of raw materials, processing methods, the use of colouring, and packaging products. The 
implementation of science and technology for community services is intended to provide education and training that involves fish processing group especially women group of processor. By carrying out this activity, women group of processor can directly involved to follow each of the steps set out together to overcome the problems in order to increase the production of a high quality, food sanitation and hygiene as well as the continuous increase of production and expand the market. This activity gives benefit to the fish processor group especially women group to repair their economy of family and increase social welfare, as well as the development of fishery products in North Sulawesi.

Keywords: Smoked skipjack, women group, sanitation and hygiene

\section{PENDAHULUAN}

Ikan cakalang (Katsuwonus pelamis) merupakan salah satu produk perikanan yang cukup menonjol di Sulawesi Utara khususnya kota Bitung. Ikan cakalang selain dipasarkan dalam bentuk segar juga dalam bentuk olahan seperti ikan cakalang asap atau lebih populer dengan sebutan ikan cakalang fufu.

Ikan cakalang termasuk bahan pangan yang bersifat perishable food yaitu mudah mengalami pembusukan. Untuk menjaga ikan cakalang tetap bermutu baik dan bertahan lama, maka dilakukan pengawetan dan pengolahan. Salah satu metode pengawetan dan pengolahan adalah dengan cara pengasapan.

Kelemahan dari produk olahan ikan cakalang asap adalah hasil olahannya tidak dapat bertahan lebih dari 2 (dua) hari penyimpanan karena nilai gizinya mulai menurun, olahannya mulai terasa gatal. Disamping masalah tersebut hal lain yang perlu ditangani adalah produk tidak dikemas dengan baik sehingga peluang terjadinya kontaminasi pada produk sangat besar.

\section{TINJAUAN PUSTAKA \\ Pengesan Ikan di Cooler box}

Pada pengesan ikan, beban penerimaan panas total didalam peti itu paling sedikit berasal dari 3 sumber pengaliran panas, yakni dari :

a. Beban penerimaan panas melalui sisi tutup dan alas peti

b. Beban panas oleh pergantian udara

c. Beban panas dari muatan produk dalam peti

d. Beban panas lainnya
Beban panas total diperoleh dengan menjumlahkan ketiga sumber panas itu. Secara konvensional beban panas total itu masih ditambah sebesar $10 \%$ sebagai faktor pengganti.

Disamping perlu menyediakan jumlah es yang cukup untuk mendinginkan ikan mencapai $0^{\circ} \mathrm{C}$, yang ditambah pula dengan sejumlah es lagi untuk mengatasi atau merefrigerasi beban panas lainnya (beban panas yang berkonduksi melalui dinding peti dan beban panas oleh pergantian dan penetrasi udara), maka cara menempatkan es (atau cara pengesan) di sekitar ikan atau selapis ikan dalam peti akan sangat menentukan kecepatan pendinginan pada pusat thermal seekor ikan besar atau bagian tengah dari satu lapis ikan.

\section{Pengawetan Ikan dengan Cara Pengasapan}

Proses pengasapan merupakan salah satu cara pengawetan ikan yang sejak lama banyak dilakukan oleh petani ikan atau nelayan dinegara kita. Menurut Afrianto dan Liviawaty (1989) saat ini hampir 20\% dari hasil tangkapan diolah dengan cara pengasapan.

\section{Prinsip Dasar Sanitasi dan Hygiene}

Sanitasi adalah ilmu terapan berupa tindakan pencegahan penyakit dengan tujuan pengamanan. Hal ini dapat dilakukan dengan cara melenyapkan atau mengendalikan fisik seperti peralatan, tenaga kerja dan lingkungan pabrik. Menurut Winarno (1994) bahwa tujuan sanitasi adalah untuk mencegah masuknya kontaminan kedalam makanan dan peralatan pengolahan yang digunakan dalam pengolahan makanan serta mencegah terjadinya kontaminasi ulang. 
Prinsip-prinsip dasar sanitasi (Winarno, 1994) adalah:

1. Pemusnahan mikroba, sisa-sisa makanan, debu dan tanah yang memungkinkan timbulnya mikroba yang tidak dikehendaki

2. Penggunaan cara-cara fisik dan mekanis atau zat-zat kimia (tentu saja setelah proses pembersihan) dengan maksud untuk memusnahkan sebagian besar mikroba yang masih tertinggal pada permukaan peralatan

Menurut Adawyah (2007), hygiene adalah ilmu yang berkaitan dengan pencegahan penyakit dan pemeliharaan kesehatan. Pencegahan penyakit dan pemeliharaan kesehatan disini meliputi bahan pangan, peralatan yang digunakan, dan bahanbahan tambahan lain yang tidak membahayakan kesehatan.

\section{METODE PENELITIAN}

Setelah selesai melakukan survey lapangan kemudian ditetapkan kelompok pengolah ikan cakalang fufu yang berlokasi di kelurahan Girian Atas kota Bitung sebagai kelompok mitra yaitu sebagai subjek pelaksanaan kegiatan pengabdian kepada masyarakat (PKM). Kegiatan persiapan yang dilakukan meliputi: kegiatan administrasi surat-menyurat, pengadaan alat dan bahan untuk pelatihan. Waktu pelaksanaan yang ditetapkan sesuai dengan surat tugas pelaksanaan kegiatan yaitu bulan Juni sampai dengan September 2020.

Untuk melaksanakan kegiatan PKM kelompok perempuan pengolah ikan cakalang asap (cakalang fufu) di kelurahan Girian Bawah, tim pelaksana berkoordinasi dengan pemerintah setempat, kelompok pengolah ikan tongkol asap dan penyuluh lapangan setempat. Ditetapkannya lokasi Kelurahan Girian Bawah sebagai lokasi pelaksanaan kegiatan PKM ini dengan pertimbangan bahwa pengolah ikan cakalang asap sudah melakukan usaha ini dalam jangka waktu yang cukup lama yaitu secara turun menurun dari orang tua mereka, namun usaha ini belum memberikan hasil yang maksimal dalam peningkatan kesejahteraan keluarga mereka. Dengan demikian diharapkan bahwa dengan adanya introduksi Ipteks bagi pengolah ikan cakalang asap tersebut dapat memberikan solusi yang baik bagi permasalahan yang dihadapi kelompok pengolah ikan cakalang asap serta dapat memotivasi kelompok-kelompok lainnya dalam mengembangkan dan meningkatkan usaha pengolahan ikan tongkol asap.

Dalam pelaksanaan PKM sudah dilakukan pertemuan sebanyak 10 kali yaitu sejak survey sampai dengan kegiatan pendampingan, antara lain:

1. Survey lapangan

2. Koordinasi dengan lurah setempat, penyuluh perikanan, kelompok-kelompok pengolah

3. Pemberian materi pelatihan (teori dan praktek) "Sortasi ikan sebagai bahan mentah ikan asap"

4. Pemberian materi pelatihan (teori dan praktek) "Pemakaian cooler box"

5. Pemberian materi pelatihan (teori dan praktek) "Pengasapan ikan"

6. Pemberian materi pelatihan (teori dan praktek) "Pelabelan dan pengemas vacuum"

7. Pemberian materi sanitasi lingkungan

8. Pemberian materi tentang pengelolaan keuangan dan manajemen pemasaran

9. Penyuluhan materi penguatan kelompok perempuan pengolah ikan dengan mendirikan koperasi

10. Pendampingan dilakukan sebanyak 2 (dua) kali

\section{HASIL DAN PEMBAHASAN}

Kegiatan Pengabdian Kepada Masyarakat (PKM) yang dilaksanakan pada kelompok pengolah ikan cakalang asap (cakalang fufu) di kelurahan Girian Bawah mencapai sasaran dan berhasil guna bagi kedua kelompok mitra. Kegiatan penyuluhan dan pelatihan mengenai sortasi bahan baku ikan cakalang, pengolahan ikan cakalang asap menggunakan metode yang tepat, penggunaan bahan pengemas yang saniter dan hygienis.

Pengolahan ikan cakalang asap ini telah dilakukan kelompok mitra sejak dahulu kala namun masih menghadapi berbagai kendala dalam usaha ini. Keterbatasan finansial dan sumberdaya yang ada membuat usaha ini tidak memberi hasil yang maksimal dalam peningkatan kesejahteraan kelompok pengolah dan keluarganya. Berbagai upaya telah dilakukan misalnya dengan bekerja sama dengan pemerintah kota Bitung melalui dinas kelautan dan perikanan, dan kelompok pengolah ikan asap di lokasi lainnya yang telah lebih maju usahanya. Upaya ini diakui kelompok pengolah (mitra) cukup bermanfaat dalam 
menjalankan usahanya namun itupun belum membawa hasil yang signifikan bagi peningkatan produksi dan kesejahteraan mereka.

Kegiatan ini diawali dengan melaksanakan survey lapangan ditempat pengolahan ikan asap kedua mitra. Lokasi tempat pengasapan dan lingkungan sekitarnya belum cukup memadai sebagai tempat pengolahan ikan, rumah asap masih sangat sederhana dengan peralatan pengasapan seadanya. Kebersihan lingkungan sekitar tempat pengasapan perlu mendapat perhatian tentang sanitasi dan hygienis bagi produk olahan makanan (ikan). Tempat penampungan bahan baku ikan segar yang terbatas, dimana hal ini juga mempengaruhi kualitas bahan baku untuk ikan asap. Dari percakapan yang dilakukan selama kegiatan ini, kedua kelompok pengolah menyampaikan semua keterbatasan dan kendala yang dihadapi. Mereka juga menyampaikan niat yang besar untuk perubahan usaha mereka ini ke arah yang lebih baik dengan kemauan untuk menerima masukan dari berbagai pihak.

Tahapan pertama kegiatan ini yaitu melakukan penyuluhan dan pelatihan mengenai sortasi bahan baku ikan yang berkualitas baik. Hal ini penting, karena untuk menghasilkan produk yang baik tentunya kelompok pengolah harus memperhatikan kualitas bahan baku yang digunakan. Pelatihan tentang sortasi bahan baku ini mencapai sasaran karena kelompok pengolah menunjukkan atensi dalam pelatihan ini dengan memberikan pertanyaan dan sanggahan berdasarkan pengalaman yang sering dialami.

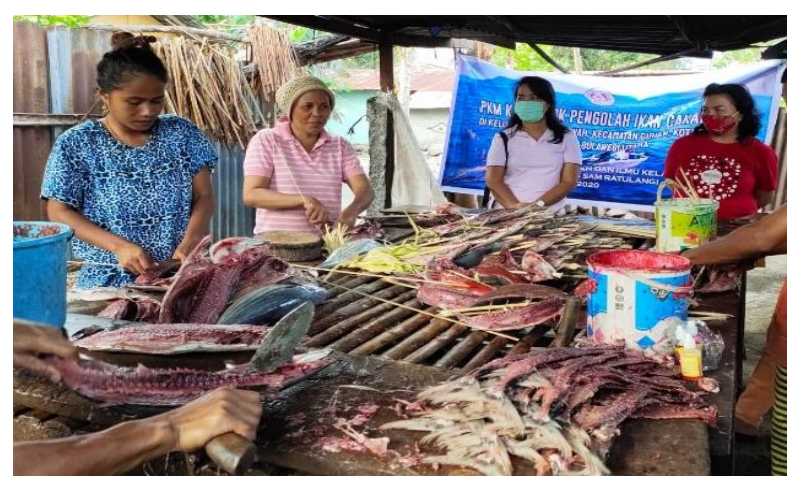

Gambar 1. Aktivitas pengolahan ikan asap

Cara penggunaan tempat penyimpanan bahan baku yaitu cooler box, serta teknik penyusunan ikan di dalam cool box juga dilakukan selama kegiatan ini, sehingga ikan yang dibeli dengan kualitas yang baik itu dapat segera disimpan dalam penyimpanan dingin. Bantuan pengadaan cooler box bagi kelompok pengolah sangat bermanfaat, juga diajarkan pula cara penggunaannya sehingga mereka dapat segera menggunakannya untuk menyimpan bahan baku ikan segar. Selama ini kendala yang mereka hadapi yaitu ketika bahan baku berlimpah dan belum dapat mengolah ikan saat itu juga, mereka tidak mempunyai tempat penyimpanan dingin agar dapat menjaga kualitas bahan baku untuk diolah keesokan harinya.

Kegiatan selanjutnya yaitu pelatihan tentang tahapan proses produksi ikan cakalang asap yang menggunakan metode yang tepat yaitu dengan memperhatikan suhu dan waktu pengasapan. Bahan bakar yang digunakan juga penting untuk menjaga suhu pengasapan sehingga kualitas ikan asap akan lebih baik. Rangka yang digunakan untuk penyanggah ikan selama pengasapan diganti dengan rangka besi yang lebih kuat untuk menampung ikan lebih banyak tiap kali pengasapan. Kebersihan selama pengolahan harus diperhatikan, yaitu sejak pencucian ikan menggunakan air bersih sehingga akan menghasilkan ikan asap yang berkualitas dan aman untuk dikonsumsi. Sangat dianjurkan untuk tidak menggunakan bahan pewarna tambahan yang sering kali menipu konsumen dengan warna merah, apalagi bahan pewarna yang digunakan tersebut berbahaya untuk digunakan sebagai pewarna bahan pangan.

Setelah selesai kegiatan penyuluhan dan pelatihan, dilakukan evaluasi keberhasilan program kegiatan PKM melalui post test. Dari 20 responden yang mengikuti post test ini terlihar bahwa terjadi peningkatan skill dan pengetahuan dari peserta yang cukup signifikan, dimana $80 \%$ dari responden (kelompok wanita pengolah ikan cakalang asap) sudah mengerti dan paham tentang materi pelatihan yang diberikan. Ke depannya diharapkan mutu ikan cakalang asap atau cakalang fufu yang dihasilkan oleh kelompok perempuan pengolah cakalang fufu ini akan makin digemari dengan mutu dan kualitas yang lebih baik.

\section{KESIMPULAN}

Agar diperoleh produk ikan cakalang fufu dengan mutu yang baik, proses 
pengolahan harus dilakukan secara rasional dan baku. mulai dari bahan baku, bahan pembantu, proses pengolahan, sampai lingkungan pengolahan. Kondisi fisik dan bakterial, komposisi kimia, serta kesegaran bahan baku dan bahan pembantu harus diketahui untuk memilih proses pengolahan yang tepat. Dengan standardisasi maka konsumen akan mendapatkan produk yang sesuai dengan yang seharusnya. Kondisi ini juga akan membuka peluang pengembangan dan pemasaran produk. Pengetahuan dan ketrampilan pengolah ikan cakalang fufu selayaknya terus ditingkatkan dan bersinergi bersama perguruan tinggi dan pemerintah.

\section{DAFTAR PUSTAKA}

Adawyah R., 2007. Pengolahan dan Pengawetan Ikan. Bumi Aksara, Jakarta.

Afrianto, E. dan Liviawaty, E., 1989. Pengawetan dan Pengolahan Ikan. Penerbit Kanisius, Yogyakarta.

Hariyadi, P., 1996. Sanitasi dan Hygiene Industri Hasil Perikanan. Jurusan Teknologi Pangan dan Gizi, Institut Pertanian Bogor.

Winarno, F.G., 1994. Sterilisasi Komersial Produk Pangan. PT Gramedia Pustaka Utama, Jakarta. 